\title{
PENGARUH VARIASI HEAT ABSORBER PLATE TERHADAP PERFORMANCE SOLAR DRYER KEMIRI
}

\author{
Mietra Anggara ${ }^{1}$, Silvia Firda Utami ${ }^{2}$ \\ ${ }^{1}$ Program Studi Teknik Mesin Fakultas Teknik Universitas Teknologi Sumbawa \\ ${ }^{2}$ Program Studi Teknik Industri Fakultas Teknik Universitas Teknologi Sumbawa \\ Corresponding Author email: ${ }^{1}$ mietra.anggara@uts.ac.id, ${ }^{2}$ silvia.firda.utami@uts.ac.id
}

\begin{tabular}{|c|c|}
\hline & ABSTRACT \\
\hline Diterima & Indonesia one of the plants that leaves and seeds grow has many useful benefits for human \\
\hline Bulan Januari & life, namely candlenut. The post-harvest handling of candlenut at the farm level it is \\
\hline 2020 & aditionally where candlenut is drying on the \\
\hline Diterbitkan & nced by the intensity of solar radiation on \\
\hline Bulan Februari & temperature and drying time according to the required hazelnut content. the dry hazelnut \\
\hline 2020 & can use solar radiation power that is solar dryer. Absorbent plate is one component that is \\
\hline & very important because it functions to absorb the intensity of solar radiation and \\
\hline Keyword : & it into heat energy and move it to the workpiece (candlenut) above it. In this study, testing \\
\hline Candlenut, & was done on variations of the absorbent plates of zinc, aluminum and iron as well as \\
\hline dryer, absorbent & variations in the thickness of the absorbent plates. Data collection starts at 09:00 until \\
\hline plate, Candlenut & 15:00 WITA in sunny weather conditions. The results showed that the aluminum \\
\hline water content & absorbent plate with a thickness of $0.04 \mathrm{~mm}$ was more effective and efficient in drying \\
\hline & the candlenut. The highest absorbent plate \\
\hline & e aluminum absorbent plate with a thickness \\
\hline & of 6 hours and meets the standard of moisture \\
\hline
\end{tabular}

\section{PENDAHULUAN}

Di Indonesia tumbuh salah satu hasil tanaman yang daun dan biji memiliki banyak manfaat yang berguna bagi kehidupan manusia yaitu kemiri. Salah satunya di Kabupaten Sumbawa tepatnya di Kecamatan Batulanteh, Desa Batu Dulang merupakan penghasil kemiri tertinggi dengan luas lahan sebesar 595.7 ha dan total produksi sebesar 285.17 ton dari data BPS 2017. Inti kemiri telah digunakan untuk berbagai tujuan baik sebagai bahan dasar bumbu masak dan bahan farmasi. Biji kemiri tergolong buah batu karena berkulit keras menyerupai tempurung dengan permukaan luar yang kasar berlekuk. Tempurung biji ini tebalnya sekitar $3-$ $5 \mathrm{~mm}$, berwarna coklat atau kehitaman. Kemiri yang bersumber dari suatu daerah memiliki tingkat kekerasan (firmness) yang berbeda dengan daerah yang lain, Anonim 2016.

Dalam penanganan pasca panen kemiri ditingkat petani umumnya masih dilakukan secara tradisional dimana menjemur kemiri di lantai atau para-para dan pemecahan biji kemiri masih menggunakan alat pemecah sederhana. Cara tradisional kurang efektif dan efsien karena proses pengeringan kemiri masih bergantung pada sinar matahari dengan suhu rata-rata $36^{\circ} \mathrm{C}$, sehingga mereka membutuhkan waktu kurang lebih 7-9 hari untuk mendapatkan hasil pengeringan sesuai. Menurut Darmawan 2017, seorang pekerja hanya mampu memecah kemiri 9 -10 kg kemiri/hari. Hal ini menimbulkan kelelahan kerja yang tinggi, disamping itu banyak inti yang pecah dan hancur (persentase inti bulat utuh hanya $40-60 \%$ ) sehingga harga kemiri menjadi lebih murah.

Tarigan 2007 dalam penelitiannya, pada proses produksi inti kemiri tingkat kadar air sangat menentukan keutuhan dan kelengketan inti pada tempurung (cangkang) kemiri. Mendapatkan tingkat kadar air yang paling sesuai untuk proses pemecahan kemiri adalah 4 sampai $6 \%$ bk (basis kering). Hal ini di dukung dengan bukti bahwa beberapa kerusakan kernel ditemukan dalam sampel dengan tingkat kadar air lebih rendah dari 3\% bk. Waktu yang lama mempengaruhi mikroorganisme yang hidup dalam kemiri dan memungkinkan mikroorganisme merusak kualitas dari kemiri itu sendiri, sehingga dibutuhkan waktu yang lebih cepat untuk pengeringan. Dalam pengeringan kemiri dipengaruhi oleh intensitas radiasi matahari terhadap temperature dan lama waktu pengeringan sesuai dengan kadar air kemiri yang dibutuhkan. Hasil penelitian menunjukkan bahwa pada musim kemarau tersedia intensitas radiasi matahari paling besar dalam satu tahun. Pada penelitian selanjutnya mengemukakan tenaga matahari merupakan solusi yang menjanjikan 
untuk menghemat biaya, Astawa 2008. Selain itu, penelitian dari Duffie dan Beckman 2003, intensitas radiasi matahari yang jatuh ke bumi yaitu rata - rata 1,4 $\mathrm{kWh} / \mathrm{m}^{2}$.hari. Sehingga untuk mengeringkan kemiri dapat menggunakan tenaga radiasi matahari yaitu solar dryer.

Pada sistem solar dryer kemiri yang memanfaatkan tenaga surya sebagai sumber energi, pelat penyerap merupakan salah satu komponen yang sangat berperan penting karena berfungsi menyerap intensitas radiasi matahari dan mengkonversikannya menjadi energi panas serta memindahkannya ke benda kerja (kemiri) yang berada diatasnya. Kemudian kemiri yang dipanaskan akan mengalami penguapan dengan berkurangnya kadar air. Dalam penyerapan dan pemindahan panas pada pelat penyerap dipengaruhi oleh ketebalan, warna dan bahan dasar yang digunakan dari pelat penyerap. Dari permasalahan diatas maka perlu dilakukan penelitian tentang pengaruh variasi heat absorber plate terhadap performance solar dryer kemiri.

\section{METODE PENELITIAN}

Penelitian ini merupakan penelitian eksperimental skala laboratorium yang bertujuan untuk mengetahui pengaruh variasi heat absorber plate terhadap performance solar dryer kemiri.

\section{Waktu dan Tempat}

Penelitian ini direncanakan akan dilaksanakan pada bulan Mei - Juli 2019. Tempat penelitian direncanakan di Laboratorium Konversi Energi Jurusan Teknik Mesin Fakultas Teknik Universitas Teknologi Sumbawa.

\section{Bahan dan Alat Penelitian \\ Bahan Penelitian}

Bahan penelitian yang digunakan adalah kemiri yang dikeringkan dengan pemanfaatan radiasi matahari. Selain itu untuk pelat penyerap yang digunakan dari bahan seng, alumunium dan besi.

Alat Penelitian

Alat penelitian yang digunakan dalam penelitian ini adalah solar dryer dengan spesifikasi alat sebagai berikut : Pelat penyerap seng, alumunium dan besi, tebal pelat penyerap $0,4 \mathrm{~mm}, 1 \mathrm{~mm}$ dan $2 \mathrm{~mm}$, dengan panjang pelat penyerap : $60 \mathrm{~cm}$, lebar pelat penyerap : $40 \mathrm{~cm}$, tinggi dinding bagian depan : $15 \mathrm{~cm}$, tinggi dinding bagian belakang : $34 \mathrm{~cm}$. Kaca penutup satu sisi tebal $3 \mathrm{~mm}$ dengan orientasi menghadap utara-selatan. Isolator dari bahan styreofoam dengan ketebalan $5 \mathrm{~cm}$. Sudut kemiringan kaca penutup $18^{\circ}$. Dinding menggunakan kaca bening $5 \mathrm{~mm}$.

\section{Variabel Penelitian}

Pada penelitian ini terdapat 3 variabel penelitian yang digunakan, yaitu variabel bebas, variabel terikat, dan variabel terkontrol. Variabel bebas adalah pelat dari bahan seng, alumunium dan besi. Variabel terikatnya adalah Kinerja solar dryer kemiri, Temperature pelat penyerap $\left({ }^{\circ} \mathrm{C}\right)$, Lama waktu Pengeringan (Jam), dan Kadar air kemiri (\%). Sedangkan variabel terkontrolnya adalah kemiri yang diambil di desa Batu Dulang Kabupaten Sumbawa Besar.

\section{Instalasi Penelitian}

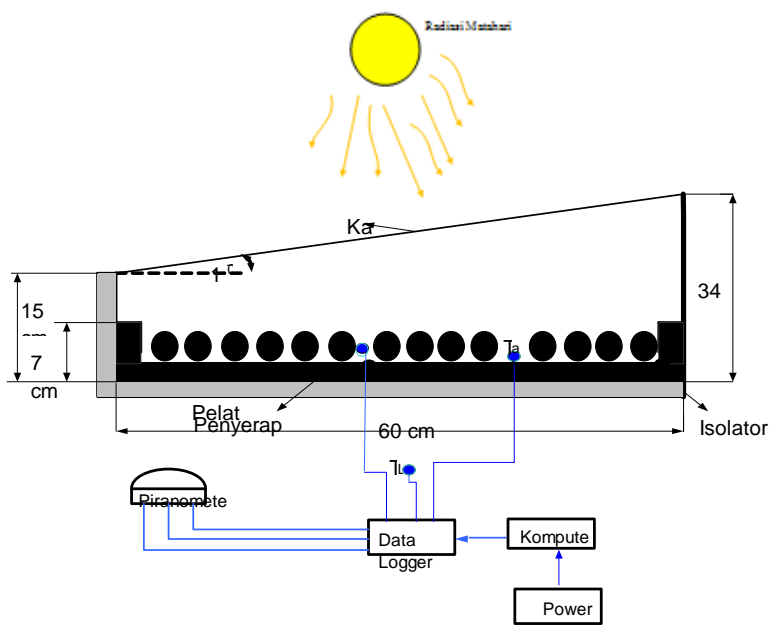

Gambar 1. Instalasi Penelitian

\section{Prosedur Pengambilan Data}

Pengamabilan data dimulai pada pukul 10.00 sampai dengan pukul 14.00 WITA dalam kondisi cuaca cerah dengan prosedur sebagai berikut.

Tahap awal meletakkan 3 buah alat solar dryer dibawah radiasi matahari secara langsung, dan memposisikannya sesuai dengan arah matahari untuk daerah Sumbawa dengan posisi $9,7^{\circ} \mathrm{LS}$ dan $118,22^{\circ}$ BT untuk bulan mei - juli 2019. Posisi matahari akan cenderung pada lintang utara, sehingga alat solar dryer diposisikan menghadap utara - selatan. Kemudian kemiri dimasukkan ke dalam alat solar dryer dengan jumlah yang sudah ditentukan, tidak dilakukan penambahan kemiri dalam jangka waktu satu hari. Untuk mengetahui jumlah kadar air pada kemiri yang berkurang dalam waktu satu hari. Selanjutnya melakukan pengukuran bertahap setiap selang waktu 1 jam terhadap intensitas radiasi matahari, temperatur lingkungan, dan temperatur pelat penyerap. Kemudian mengukur jumlah kadar air kemiri yang berkurang selama satu hari. Tahap akhir melakukan pengulangan pengujian untuk mendapatkan hasil yang optimal. 
Diagram Alir Penelitian

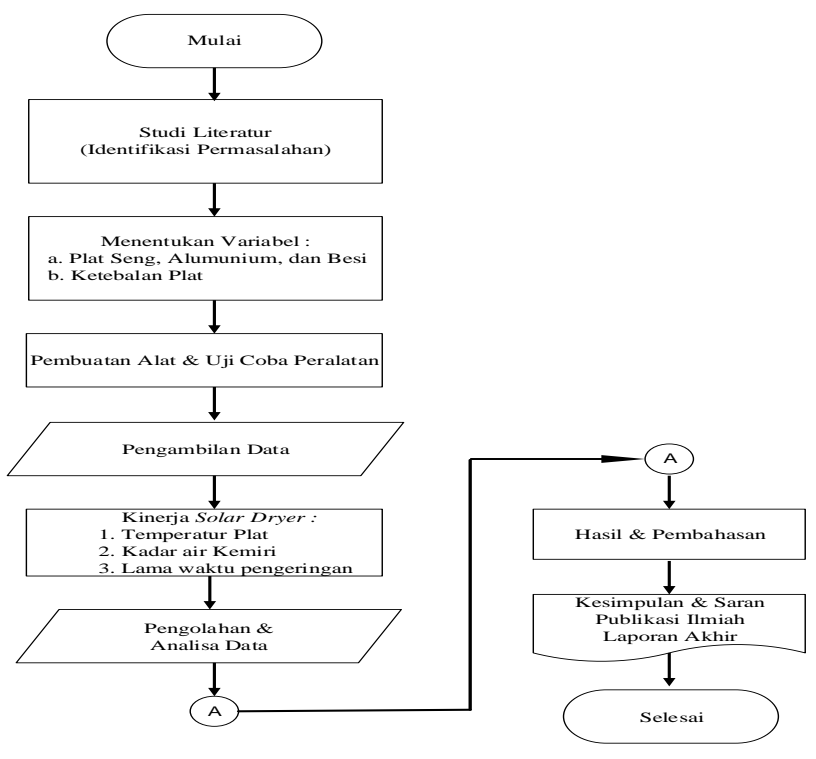

Gambar 2. Diagram Alir Solar Dryer Kemiri

\section{HASIL DAN PEMBAHASAN}

Penelitian skala laboratorium yang dilakukan adalah untuk mengetahui pengaruh variasi heat absorber plate terhadap performance solar dryer kemiri. Pengujian yang dilakukan pada variasi dan ketebalan heat absorber plate. Variasi pelat penyerap panas yang digunakan yaitu besi, seng dan alumunium sedangkan ketebalan plat yang digunakan $0.4 \mathrm{~mm}, 1 \mathrm{~mm}$ dan $2 \mathrm{~mm}$ dengan melihat hasil pengujian pelat yang terbaik dari variasi pelat yang digunakan. Pelaksanaan pengujian langsung dibawah sinar radiasi matahari. Adapun hasil pelaksanaan pengujian terdapat pada sub bab berikutnya.

\section{Data Radiasi Matahari pada pengujian variasi dan ketebalan Heat Absorber plate}

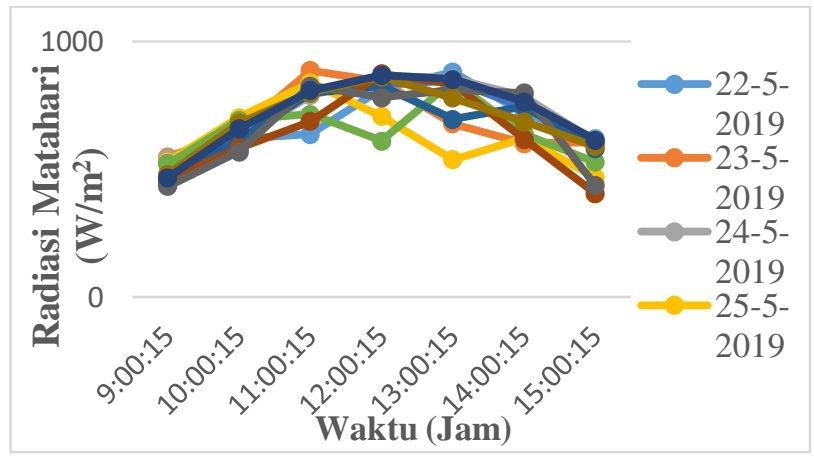

Gambar 3. Intensitas radiasi matahari terhadap waktu pada pengujian variasi dan ketebalan heat absorber plate
Intensitas radiasi matahari yang direkam oleh data logger menggunakan pyranometer selama pengujian cukup bervariasi, namun membentuk pola yang sama. Radiasi total yang diterima mulai pukul 09.00 WIB naik perlahan-lahan kemudian akan mencapai puncaknya antara pukul 10.30 WIB sampai dengan pukul 12.00 WIB. Setelah itu radiasi matahari yang diterima mengalami penurunan secara perlahan hingga pukul 15.00 WIB. Radiasi matahari total yang diterima oleh pyranometer bervariasi yaitu $541 \mathrm{~W} / \mathrm{m}^{2}$ pada pagi hari, $866 \mathrm{~W} / \mathrm{m}^{2}$ pada siang hari dan $609 \mathrm{~W} / \mathrm{m}^{2}$ pada sore hari.

Proses pengeringan terjadi karena intensitas radiasi matahari diserap oleh pelat penyerap yang akan meningkatkan temperatur ruangan, kemudian memanaskan kemiri sehingga kadar air kemiri akan berkurang. Intensitas radiasi matahari untuk setiap waktunya berbeda (gambar 3), hal ini disebabkan kondisi cuaca cerah dan berawan atau mendung. Intensitas radiasi matahari yang diterima oleh solar dryer berpengaruh terhadap pengeringan dan produksi kemiri. Karena semakin besar intensitas radiasi matahari yang diserap oleh pelat penyerap menunjukkan semakin besar energi yang diterima oleh pelat penyerap yang digunakan untuk mengeringkan kemiri. Sehingga dengan peningkatan intensitas radiasi matahari dapat mengeringkan biji kemiri dan meningkatkan produksi kemiri.

\section{Data Temperatur pada Variasi Heat absorber plate}

Pada variasi jenis pelat penyerap panas yang berada di dalam alat pengering mempengaruhi temperatur pelat penyerap dan lama waktu pengeringan terhadap intensitas radiasi matahari yang ditunjukkan pada gambar grafik dibawah ini.

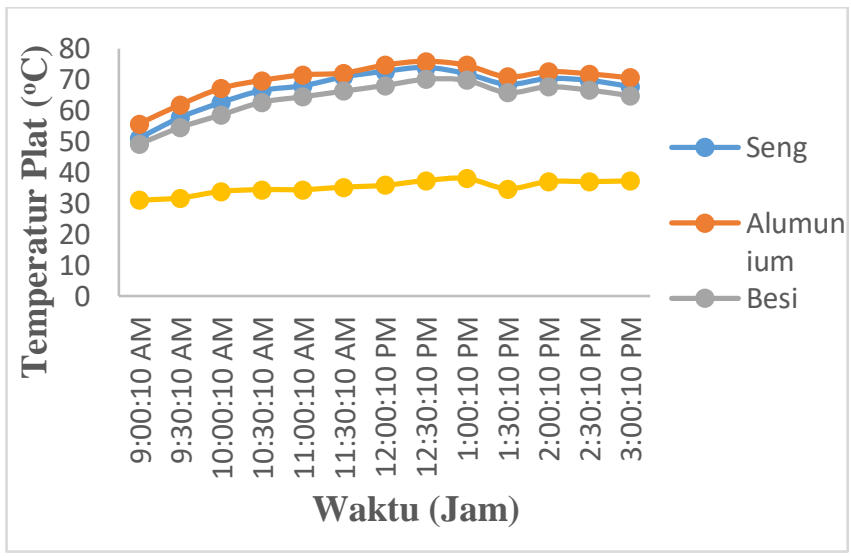

(a)

ISSN 2527-970X | E-ISSN 2621- 542x 


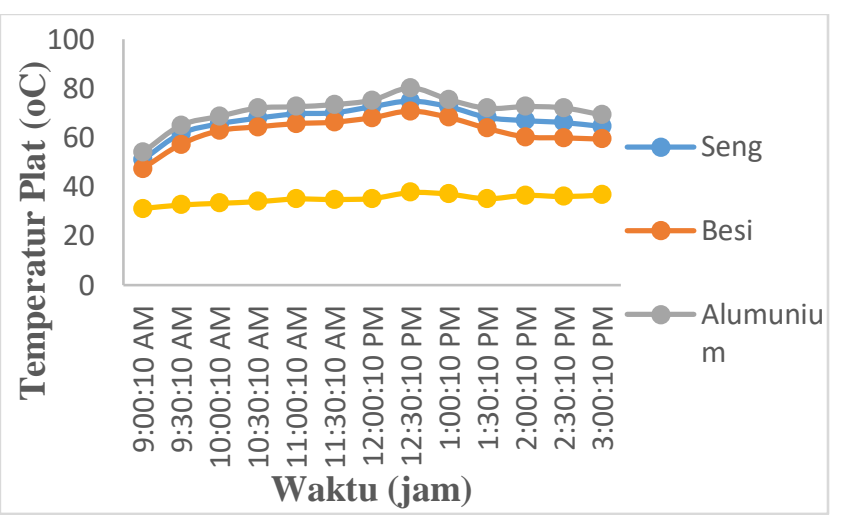

(b)

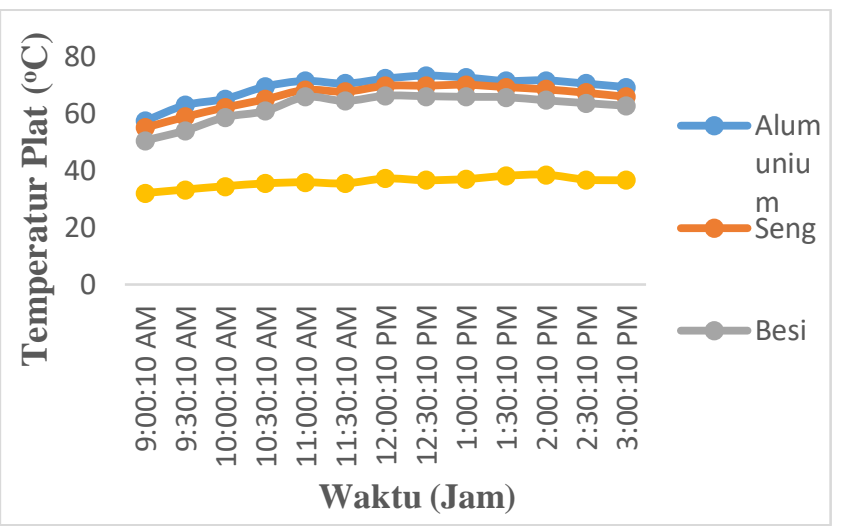

(c)

Gambar 4. Temperatur Variasi Heat Absorber Plate Terhadap Waktu

Pada tanggal (a) 24 Mei 2019, (b) 25 Mei 2019 dan (c) 26 Mei 2019

Pada gambar 4. (a), (b) dan (c) diatas terlihat temperatur pelat penyerap mengalami pola yang sama dengan panas radiasi matahari. Karena potensi panas radiasi matahari penyebab utama dalam mempengaruhi temperatur pelat penyerap jenis alumunium, seng dan besi, ketika langsung terkena panas radiasi matahari. Pada pelat penyerap panas radiasi matahari dari alumunium memiliki temperatur pelat penyerap tertinggi pada radiasi harian matahari terendah dibandingkan dengan pelat seng dan pelat besi. Tingginya temperatur pelat penyerap alumunium dalam menyerap panas dipengaruhi oleh konduktifitas termal yang tinggi yang dimiliki oleh pelat alumunium. Hal ini menunjukkan proses perpindahan panas keseluruh permukaan pelat lebih cepat. Dengan demikian panas pada seluruh bagian pelat alumunium lebih cepat merata. Sehingga dengan mudah dan cepat dalam memindahkan panas ke benda kerja khususnya kemiri untuk dikeringkan.
Sedangkan pelat penyerap panas pada seng dan besi lebih lambat dalam menghantarkan panas untuk mengeringkan kemiri. Panas yang dipindahkan kebagian tengah dan bawah pada pelat penyerap serta kemiri yang berada diatasnya akan mengalami proses perlambatan dan pengurangan panas. Hal ini dipengaruhi oleh konduktifitas termal yang dimiliki oleh kedua jenis pelat tersebut. Sehingga mengurangi penyerapan radiasi matahari yang diubah menjadi energi panas pada pelat penyerap menyebabkan proses pengeringan kemiri membutuhkan waktu yang lebih lama. Pada gambar grafik (b) pengujian pada tanggal 25 mei 2019 merupakan salah satu intensitas radiasi matahari tertinggi dengan rata-rata $724 \mathrm{~W} / \mathrm{m}^{2}$. Temperatur pelat penyerap tertinggi terdapat pada pelat peneyerap alumunium dengan besar temperatur 70.93 ${ }^{\circ} \mathrm{C}$, pada pelat penyerap seng $67.04{ }^{\circ} \mathrm{C}$, sedangkan temperatur terendah pada pelat penyerap besi dengan besar temperatur $62.63^{\circ} \mathrm{C}$.

\section{Data Kadar Air Kemiri pada Variasi Heat Absorber Plate

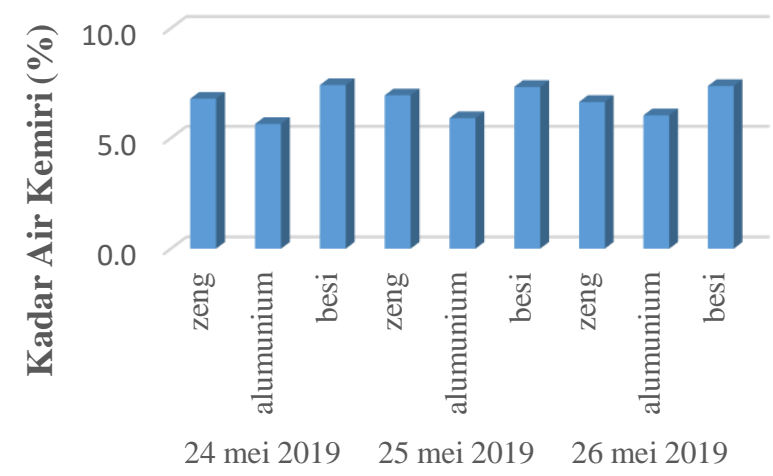 \\ Waktu (hari)}

Gambar 5. Kadar air kemiri pada variasi heat absorber plate

Untuk mengetahui kinerja solar drayer dalam proses pengeringan kemiri, perlu diketahui standar kadar air kemiri yang digunakan untuk proses pemecahan kemiri. Untuk tingkat kadar air yang paling sesuai dalam proses pemecahan kemiri adalah 4 sampai $6 \%$ bk (basis kering). Hal ini didukung dengan bukti bahwa beberapa kerusakan kernel ditemukan dalam sampel dengan tingkat kadar air lebih rendah dari 3\% bk. Waktu yang lama mempengaruhi mikroorganisme yang hidup dalam kemiri dan memungkinkan mikroorganisme merusak kualitas dari kemiri itu sendiri, sehingga dibutuhkan waktu yang lebih cepat untuk pengeringan.

Besarnya intensitas radiasi matahari yang diserap dan dipindahkan ke benda kerja mempengaruhi proses laju pengeringan pada kemiri. Laju pengeringan akan semakin cepat dengan menurunnya kadar air pada 
kemiri yang dikeringkan. Hal ini terjadi pada jumlah kadar air kemiri pada pelat penyerap panas alumunium sudah memenuhi standar kadar air kemiri dalam pemecahan kemiri dengan lama waktu pengeringan selama 6 jam. Sedangkan kadar air pada pelat penyerap seng dan alumunium belum memenuhi standar kadar air pemecahan kemiri sehingga membutuhkan penambahan waktu dalam pengeringan kemiri. Dari ketiga jenis pelat penyerap panas ini yang lebih efisien dalam mengeringkan kemiri adalah pelat penyerap alumunium. Hasil pengujian pada gambar 5 tanggal 25 mei 2019 tingkat kadar air kemiri yang sudah memenuhi standar pemecahan kemiri yaitu pada pelat penyerap panas alumunium dengan kadar air $5.9 \%$. Sedangkan pada pelat penyerap panas seng dengan kadar air $6.9 \%$ dan pelat penyerap panas besi dengan kadar air $7.3 \%$ dengan durasi pengeringan selama 6 jam.

\section{Data Temperatur Ketebalan Heat Absorber Plate}

Pada variasi ketebalan pelat penyerap panas yang berada di dalam alat pengering mempengaruhi temperatur pelat penyerap dan lama waktu pengeringan terhadap intensitas radiasi matahari yang ditunjukkan pada gambar grafik dibawah ini.

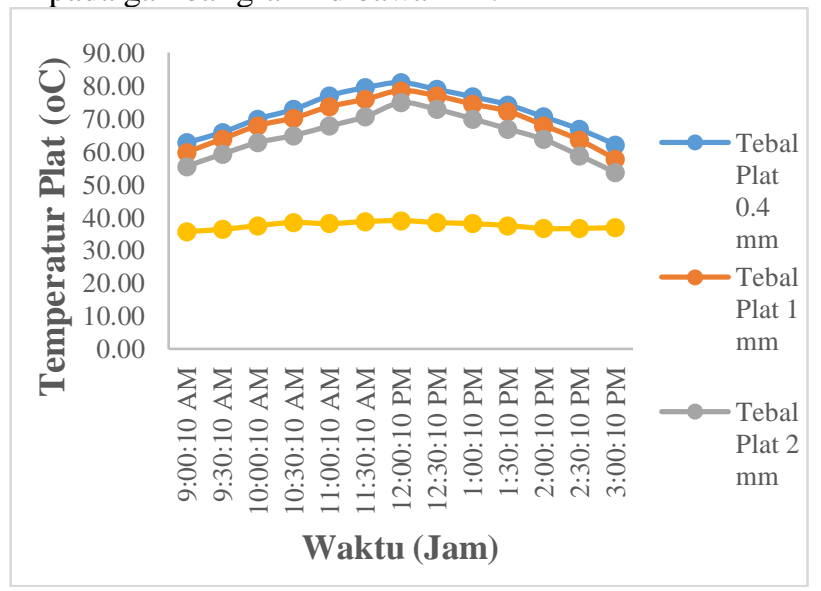

(a)

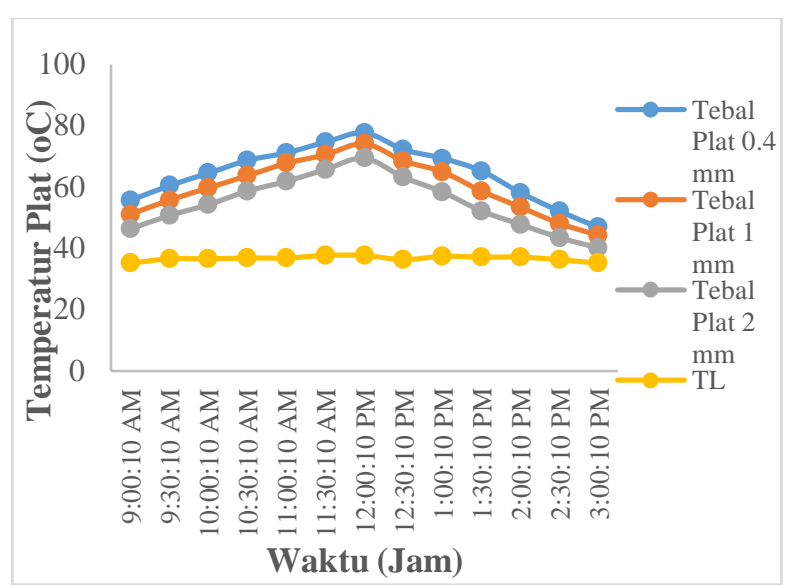

(b)

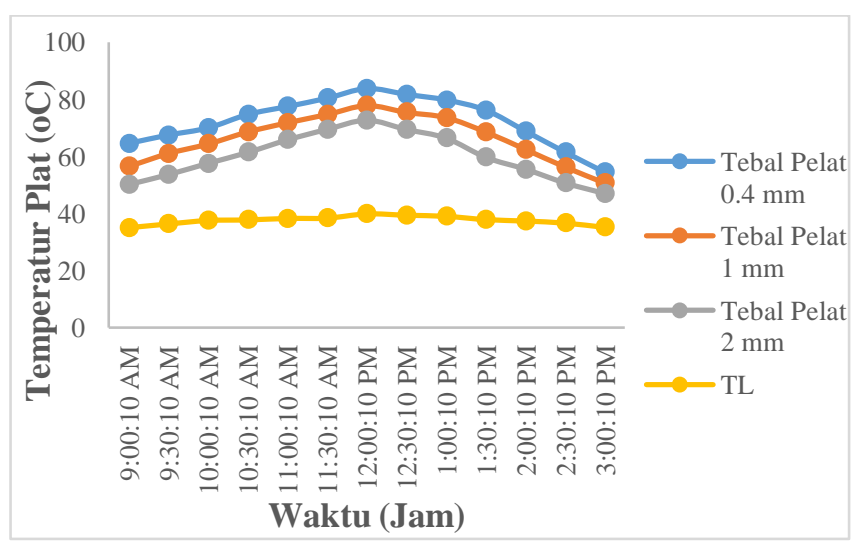

(c)

Gambar 6. Temperatur ketebalan heat absorber plate terhadap waktu

pada tanggal (a) 11 Juni 2019, (b) 14 Juni 2019 dan (c) 15 Juni 2019

Kemampuan laju konduksi kalor dalam menyerap dan menghantarkan kalor dipengaruhi oleh ketebalan plat penyerap. Semakin tebal penyerap maka semakin lambat dalam perpindahan panas. Sehingga kemiri yang dikeringkan mengalami pertambahan waktu dengan jumlah temperatur yang kurang. Sedangkan proses pengeringan kemiri membutuhkan temperatur yang cukup tinggi dengan waktu cepat sehingga produksi kemiri semakin meningkat.

Berdasarkan pada grafik gambar 6 diatas menunjukkan bahwa ketebalan plat penyerap panas mempengaruhi temperatur dan waktu pengeringan kemiri. Hal ini ditunjukkan dari salahsatu pengujian pada tanggal 15 Juni 2019, temperatur tertinggi terdapat pada plat penyerap alumunium dengan ketebalan 0.4 $\mathrm{mm}$ dengan rata-rata temperature $72.36^{\circ} \mathrm{C}$. Sedangkan pada ketebalan plat alumunium $1 \mathrm{~mm}$ dengan rata-rata temperature $66.25{ }^{\circ} \mathrm{C}$ dan ketebalan plat alumunium 2 $\mathrm{mm}$ dengan rata-rata temperatur terendah $59.94{ }^{\circ} \mathrm{C}$ 
dengan rata-rata radiasi matahari $719 \mathrm{~W} / \mathrm{m}^{2}$. Hal ini disebabkan karena ketebalan plat $0.4 \mathrm{~mm}$ lebih cepat menyerap dan memindahkan kalor keseluruh permukaan plat dengan baik. Sesuai dengan laju konduksi kalor semakin tebal pelat maka semakin lambat perpindahan kalor. Sehingga ketebalan plat penyerap alumunium yang efisien dalam menyerap dan menghantarkan panas pada pengeringan kemiri yaitu ketebalan plat $0.4 \mathrm{~mm}$ dengan temperatur $72.36^{\circ} \mathrm{C}$ dan waktu pengeringan selama 6 jam.

\section{Kadar Air Kemiri Pada Pengujian Ketebalan Heat Absorber Plate}

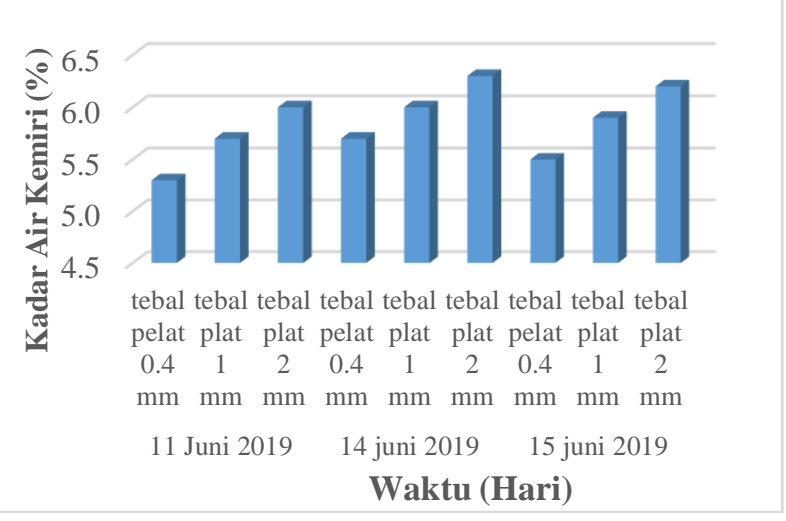

Gambar 7. kadar air kemiri pada pengujian ketebalan heat absorber plate

Hasil penelitian menunjukkan pada gambar 7 bahwa pelat penyerap panas pada alumunium lebih efektif dan efisien dalam mengeringkan kemiri. Jumlah kadar air hasil pengeringan kemiri terbaik terdapat pada salah satu pengujian tanggal 11 Juni 2019 pada ketebalan $0.4 \mathrm{~mm}$ dengan jumlah kadar air $5.3 \%$, pada ketebalan $1 \mathrm{~mm}$ dengan jumlah kadar air $5.7 \%$ dan pada ketebalan $2 \mathrm{~mm}$ terendah dengan kadar air 6.0\%. Hal ini disebabkan oleh laju pengeringan pada ketebalan plat $0.4 \mathrm{~mm}$ dalam meyerap dan menghantarkan panas ke benda kerja lebih cepat dibandingkan dengan ketebalan plat penyerap yang lain. Sehingga ketebalan pelat penyerap panas $0.4 \mathrm{~mm}$ pada alumunium lebih efisien dalam mengeringkan kemiri sesuai dengan kadar air kemiri yang dibutuhkan

\section{PENUTUP}

Kesimpulan

Beberapa kesimpulan yang dapat ditarik dari penelitian diatas adalah :

1. Pelat penyerap alumunium dengan ketebalan $0.04 \mathrm{~mm}$ lebih efektif dan efisien dalam pengeringan kemiri sehingga dapat meningkatkan produktifitas kemiri.

2. Temperatur plat penyerap dan lama waktu pengeringan tertinggi terdapat pada plat penyerap alumunium dengan ketebalan 0.4 $\mathrm{mm}$ yaitu $72.36{ }^{\circ} \mathrm{C}$ dan lama waktu pengeringan 6 jam.

3. Penggunaan plat alumunium dengan ketebalan $0.04 \mathrm{~mm}$ sudah memenuhi standar kadar air pemecahan kemiri yaitu $5.3 \%$.

\section{REFERENSI}

Anggara, Dkk. 2016. Pengaruh Ukuran Butir Pasir Besi Dan Volume Air Laut Pada Absorber Type Fins Solar Destillation Terhadap Produktifitas Air Tawar. Journal Rekayasa Mesin. Malang : Universitas Brawijaya

Anonim. 2006. Pedoman budidaya kemiri (aleurites molucana wild). Departemen Pertanian. Direktorat Jenderal Perkebunan Indonesia.

Arlene A. 2010. Pengaruh Temperature dan Ukuran Biji Terhadap Perolehan Minyak Kemiri Pada Ekstraksi Biji Kemiri Dengan Penekanan Mekanis. Diunduh pada: http://repository.upnyk.ac.id/589/1/46.pdf.

Astawa, K. 2008. Pengaruh Penggunaan Pipa Kondensat Sebagai Heat Recorvery Pada Basin Type Solar Still Terhadap Efisiensi, Jurnal Ilmiah Teknik Mesin Cakram, Vol 2, No. 1, 34-41

Azridjal A. 2004. Teknologi Rekayasa Surya sebagai Pemanas Udara untuk Proses Pengeringan (Solar dryer). Jurnal Momentum. Padang (ID): Institut Teknologi Padang.

BPS. 2017. Propinsi dalam Angka. Badan Pusat Statistik Propinsi Nusa Tenggara Barat

Danhil Z. 1990. Solar Teknik 1 \& 2. Padang (ID): Universitas Andalas.

Darmawan, S., R. Kurniadi. 2007. Studi pengusahaan kemiri di Flores NTT dan Lombok NTB. Info Sosial Ekonomi Vol.7 (2) Juni 2007: 117-129.

Duffie, J.A dan Beckman, W.A 2013. Solar Engineering Of Thermal Process. Jhon willey \& Sons. New York.

El-Sebaii AA, Aboul-Enein S, Ramadan MRI, ElGohary HG. Experimental investigation of an indirect type natural convection solar dryer. Energy Convers Manage 2002; 43:2251-66. 
JURNAL TAMBORA VOL. 4 NO. 1 FEBRUARI 2020

http://jurnal.uts.ac.id

Science and Technolagy

Tarigan, E., G. Prateepchaikul, R. Yamsaengsung, A. Sirichote, P. Tekasakul. 2007. Drying characteristics of unshelled kernels of candle

nuts. Journal of Food Engineering. 79: 828833. 